\title{
Urgency of Proper E-Waste Management Plan in Nepal: An Overview
}

\author{
Jyoti Giri ${ }^{1,2,3 *}$ and Rameshwar Adhikari ${ }^{2,3,4}$ \\ ${ }^{1}$ Department of Chemistry, Tri-Chandra Multiple Campus, Tribhuvan University, \\ Kathmandu, Nepal \\ ${ }^{2}$ Central Department of Chemistry, Tribhuvan University, Kirtipur, \\ Kathmandu, Nepal \\ ${ }^{3}$ Nepal Polymer Institute (NPI), Kathmandu, Nepal \\ ${ }^{4}$ Research Centre for Applied Science and Technology (RECAST), Tribhuvan \\ University, Kirtipur, Kathmandu, Nepal \\ *Corresponding Author \\ girijys@yahoo.com
}

\begin{abstract}
Electrical and electronic gadgets (or E-gadgets) have become indispensable components of our daily life these days. As today's electrical and electronic devices become tomorrow's waste, the potential hazards of these materials in an open environment are significant, as they can contaminate soil, drinking water, air and thus directly affecting human health and surrounding biota. With time, the random disposal of these wastes may lead to a disastrous situation. Although Nepal is one of the least developed countries, also in terms of electrical and electronic equipment, we are importing the high-tech E-gadgets from the developed nations and using them without a proper vision for their after-use management and their impacts on socio-economic values as well as health and environment. It has become an urgent need of the hour to address E-waste challenges taking into consideration the best suited international policies and practices.
\end{abstract}

\section{Keywords}

E-gadget, decomposition, redesign, landfill, incineration

\section{Introduction}

According to the International Organization for Standardization (ISO), (2015) electrical and electronic gadgets (also called E-gadgets or E-wastes) are denoted as special wastes designated in the International Classification of Standards (ICS) catalog 13.030.30 (https://www. iso.org/ics/13.030/x/). Electrical and electronic devices at the end of their life, generally the old fashioned appliances, not functioning but discarded, are categorized as the E-wastes. Nowadays, in a significant part of the Earth, a person begins his day with the alarm produced by these gadgets and ends with refreshments by watching television. Besides, almost the whole day, people from different walks of life (such as officers, house-keepers, students, and health professionals use sophisticated E-gadgets to make their work comfortable and efficient. Besides, doctors, engineers, and security experts use the hi-tech E-gadgets for saving lives (Widmera et $a l .$, 2005). Thus, these materials on their working periods have become an integral part of human life (DIRECTIVE 2012/19/EU 2012, Narasimha et al., 2019; Sawhney et al., 2008).

The rapid spread of the E-gadgets in every sector of society might ultimately lead to a disastrous situation. It has been estimated that if not properly managed, the E-wastes could bring catastrophic scenarios soon in Nepal (Nepal Telecommunications Authority, 2017). Fig 1 illustrates the general condition of common 

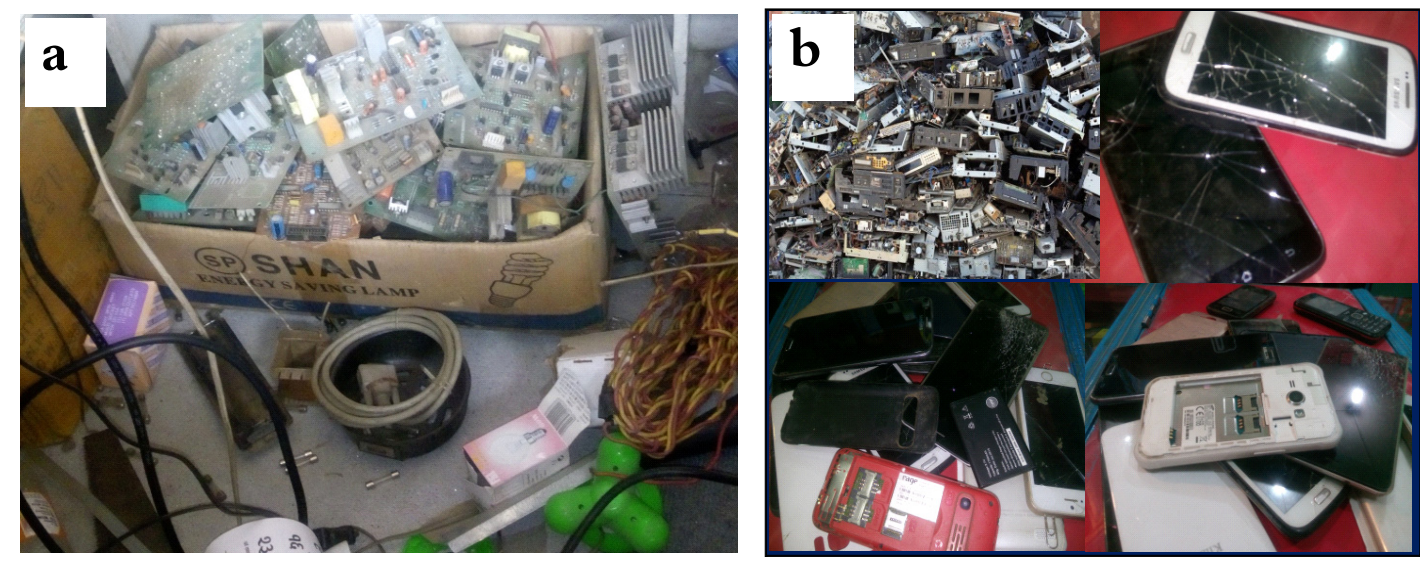

Fig. 1. Photographs of E-wastes collection in repair shops of Kathmandu: a) waste circuit boards \& cables and b) damaged cell phones $\&$ spares of the central processing unit (CPU)

electronic devices in general maintenance shops in Kathmandu. Fig 1(a) shows the electrical/ electronic compartments of E-gadgets made up of different types of plastics and metals while Fig 1(b) presents the E-gadgets collected in a repair house. Top of all, cathode ray tube (CRT) disposal is one of the biggest challenges in this field. Therefore, the production of CRT has been almost closed (Musson et al., 2000, Wu et al., 2008).

The E-gadgets comprise two significant units: i) the outer housing of polymer composites, and ii) the inner metallic, conducing-sensory units (Szalatkiewicz 2014, Narasimha et al., 2019). The outer cases and circuit boards are generally made up of polymer resins such as polyethylene (PE), polyvinyl chloride (PVC), polyurethane (PU), and polymethylmethacrylate (PMMA) (Tyagi \& Tyagi 2014). The materials are also prepared in the form of composites using different inorganic substances such as silica $\left(\mathrm{SiO}_{2}\right)$, calcium oxide $(\mathrm{CaO})$, magnesium oxide $(\mathrm{MgO})$, carbon black, graphite, alumina, etc. as fillers. Nowadays, the organic fillers are also being used due to their lightweight and as a part of green practices (Jarup 2003).

The conducting-sensory units contain various expensive metals, some of them being used to write on circuit board for acquiring unique properties such as gold $(\mathrm{Au})$, platinum $(\mathrm{Pt})$, silver $(\mathrm{Ag})$ and palladium $(\mathrm{Pd})$. The others metals, such as nickel $(\mathrm{Ni})$, tin $(\mathrm{Sn})$, lead $(\mathrm{Pb})$, chromium $(\mathrm{Cr})$, iron $(\mathrm{Fe})$, are inexpensive ones and are employed for conductivity and soldering purposes (Jarup 2003, Peterson 2009). Moreover, the composites may contain fire retardants, usually made up of hazardous chemicals such as polychlorinated biphenyl (PCB) and polychlorinated terphenyl (PCT). The latter substances exhibit toxic effects on disposal to the free environment (Peterson 2009). Thus, the E-wastes may contain many environments degrading and bio-unfriendly substances such as heavy metals and polymers along with some toxic chemicals which need proper management to save the environment and associated living beings.

This paper aims to shed light on the E-waste problematic and to raise awareness in different strata of society (ranging from manufacturers to consumers and retailers) and to encourage the implementation of so-called 3Rs (reduce, reuse and recycle) strategies as well as redesigning the production pathways.

E-waste Disposal is a Serious Problem It is known that the E-wastes directly pollute soil, underground, and surface water, as well as drinking water and air with metals and degraded microplastics directly affecting the surrounding biota. For instance, CRTs on crashing and burning, release hazardous substances such as lead $(\mathrm{Pb})$, cadmium (Cd), barium (Ba), and fluorescent powders. Polyvinyl chloride (PVC) circuit board produces toxic dioxanes, furans, and degradation products from brominated fire retardants. (Joseph 2007). Concerning human health, there 


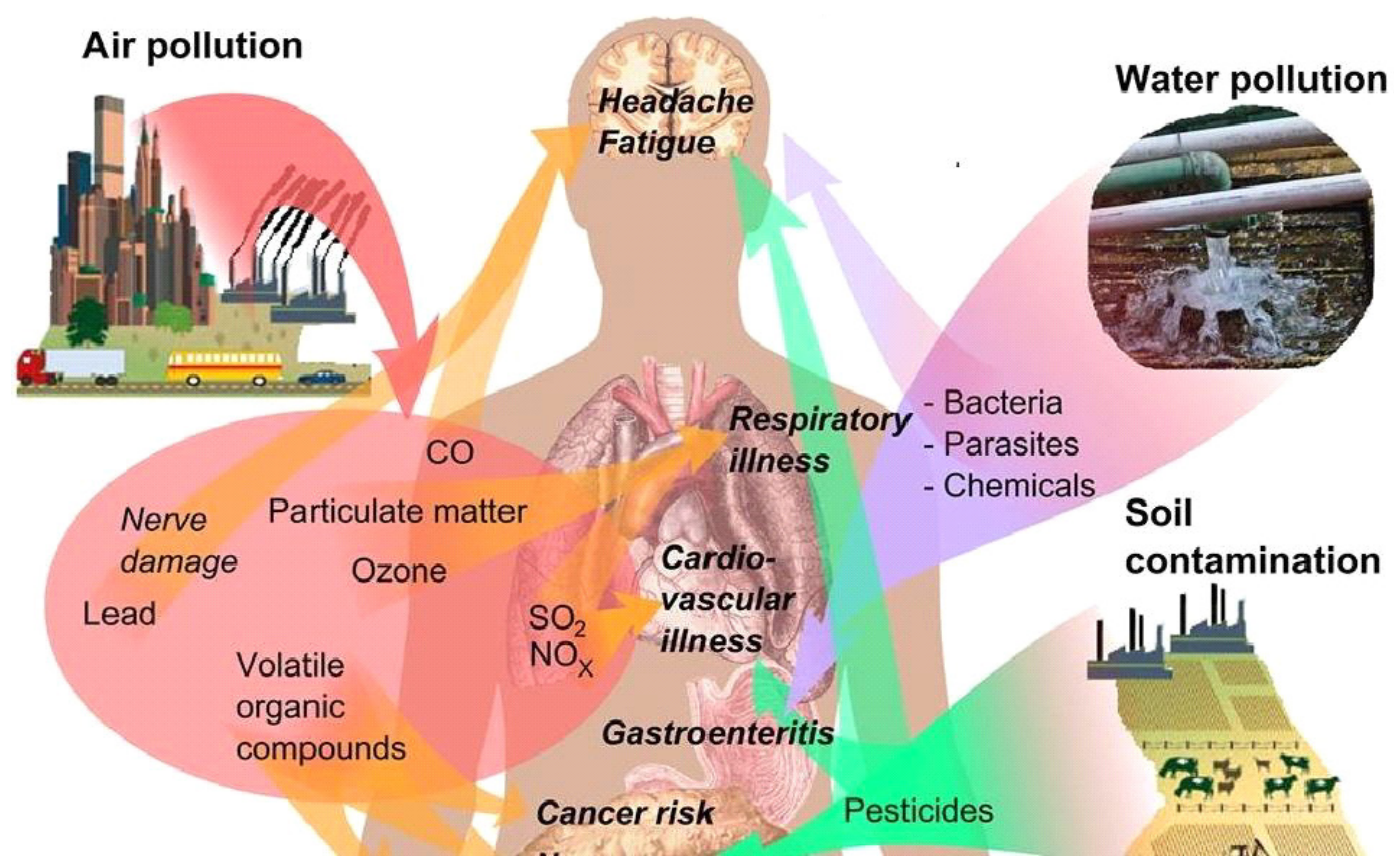

Fig. 2. Schematic diagram showing various effects of E-waste residue left in the soil, water and air to human health (Nepal telecommunications Authority 2017, Terazono et al., 2006)

are many issues reported for the disorder in the brain, lungs, kidney, liver, blood composition. It has been reported that the long term exposure to these substances progressively results in physical, muscular, and neurological degeneration, which ultimately may induce multiple sclerosis, Parkinson's disease, cancer, reproductive disorder, Alzheimer's disease, and infertility in humans.

Furthermore, vomiting, fatigue, headache, abdominal pain, diarrhea, appetite loss, and skin irritation (Hiroki 1992) are also associated with the indiscriminate discharge of E-wastes. It has to be noted that the downward diffusion of water under the soil is the most dangerous pollution disseminator and spread the contaminants in all territories. As a consequence, the ground gets infertile on a significant deposition of toxic metal ions (Oppelt 1987). In the same manner, gases produced by incineration of solid E-wastes also pollute the air with poisonous gases, which may be responsible for causing respiratory problems, ultimately leading to lung cancer and other diseases (Dreher \& Pulver 2008).

Various types of wastes and resulting pollution of natural environment and their effects on human health are depicted in Fig. 2. Besides, it is clearly shown how the natural resources like soil, water, and air get polluted by the anthropogenic activities (Terazono et al., 2006, Musson et al., 2000, Premalatha et al., 2014).

\section{International Practices of E-wastes Disposal}

There are stringent international practices in sound E-Waste management (Sawhney et al., 2008, Hoornweq \& Tata 2012). The most economically developed regions, like the EU, USA, and Japan, have adopted quite strong regulations and policies for E-waste management (Sawhney et al., 2008; Ababio 2012). Also, the economically emerging countries such as India and China have induced E-waste management in their national development policies (Joseph 2007; Chen et al., 2015; Karmacharya et al., 2015).

The global practice of waste management is "no throwing away" where system follows the procedure with a reduction in waste generation, their vehicular collection, separation, reuse, recycle, and finally the waste disposal by composting, incineration and landfilling (Hoornweq \& Tata 2012; Narasimha et al., 2019). India added recovery of metals such as copper from the circuit board on its management elements (Joseph 2007). Malaysia practices household 
management for E-waste in different ways such as recycling, giving to scrap collectors, dismantling for further applications, and selling as secondhand equipment (Kalana 2010). European Union has formulated quite strict regulatory provisions for the E-waste management (EEC No. 259/93; Directive 2002/96/EC \& Directive 2002/95/EC). The Directive 2002/95/EC is about the restriction of use of certain hazardous substances in electrical and electronic equipment. In contrast, the Directive 2002/96/EC limits the use of six harmful substances (such as lead, mercury, cadmium, hexavalent chromium, polybrominated biphenyls (PBB), and polybrominated diphenyl ethers (PBDE)) in E-gadgets (Wu et al., 2008; Mansfield 2013). The restriction of these hazardous substances in E-gadgets automatically has set a standard for production in the EU, preventing many products from being sold in the European territory that contains any of those dangerous substances (The European Communities 2003; Sawhney et al., 2008).

Moreover, Directive 2002/95/EC focuses on the production and dumping of E-gadgets. EU produces more E-waste in comparison to the USA, as the EU has a more dense human population. Both the USA and EU have opposed the E-wastes imports, but they have favored policies to send disposing such toxic wastes to developing countries, unfortunately (Sawhney et al., 2008; Mansfield 2013).

To address these challenges, the principle of 3R's (viz. Reduce, Reuse, and Recycle) is being practiced. Even a new concept for redesigning the industrial manufacturing processes have also been started (Joseph 2007; Sawhney et al., 2008; Ababio 2012; Hoornweq \& Tata 2012, Parajuly et al., 2017). Many countries are practicing 3Rs principles to address the E-waste problem. China has adopted a national policy of converting the wastes to energy. (Xu et al., 2016). Utilizing this 'waste-to-energy'strategy, in 2014, China increased its energy production from the wastes by $39 \%$ more than in 2013 , and it contributes to the total energy consumption of the whole country by $0.44 \%$ (Dunne et al., 2008). Ireland has a unique waste management policy in which the polluters have to pay. This way, the country has added a $15 \%$ tax more in the purchase of such materials, which, however, has caused a reduction in buying tendency to $92 \%$ (Zaman 2013). The astonishing results were observed in San Francesco, the USA, where in 2000 the waste was reduced to $50 \%$, in $201180 \%$, and they have targeted up to 100 $\%$ waste reduction (or zero waste planning) by 2020 (Brandl 2001). Such practices are being implemented in Italy, Nova Scotia-Canada, and many other countries.

There are many research works ongoing to overcome the terror created by E-wastes. Different methodologies of chemical and biological treatments for such wastes are being investigated. For instance, it has been reported that metal poisoning can be reduced by leaching with acids and incubation with some bacteria or fungi. The bacteria such as Thiobacillus thiooxidans, $T$. ferrooxidans and fungi such as Aspergillus niger, Penicillium simplicissimum feed on severe health hazardous, soil or water contaminants such as Zinc (Zn), Copper (Cu), Nickel (Ni), Iron (Fe), Lead (Pb), Aluminium (Al) (Widmera et al., 2005; PACE Nepal Pvt. Ltd., 2017).

Electronic wastes, in recent days, have become much more the topic of public and academic concern in the context of growing risks and hazards towards the wellbeing of humans as well as the adverse effect that can be expected for other living beings and environmental balance. The case studies highlighting the status of e-waste management strategies, including standard international practices and regulations adopted in different regions of the world, have been addressed in a recent monograph (Narasimha et al., 2019).

Also based on the experiences of several studies, it has been reported in a recent survey that the consumers are more interested in purchasing brand-new though low quality but cheaply priced electronic devices which are further instead stored due to lack of suitable disposal option (Zeng et al., 2017a, Nnorom et al., 2019).

The equipment discarded to a landfill, though a small amount, begins a new pain cycle by exposing the workers to toxic substances while processing the e-wastes in informal ways (Shaikh et al., 2020). Thus, for the sustainable management of the e-wastes, adoption of the eco-design and industrial ecology as well as 'repair-reuse-remanufacture' approaches, life cycle assessment, and innovative methods for 
the conversion of wastes into useful products including elemental recovery and targeting to new materials and energy (Chen et al., 2018; Mihai 2019; Kaya 2016). These efforts have stressed global action, including inaction of regulations, particularly avoiding the toxic materials entering the downstream and recycling and use of green stuff (Zeng et al., 2017a, Zeng et al., 2017b). report published by the Ministry of Science, Technology, showed Nepal imports 250,000 television sets and 300,000 computers every year, which, illustrates that of course, adds to our E-waste dump after a decade. The survey shows further that Nepal has 40,000 tons of lead-acid batteries used to supply power in the electronics equipment, which could bring catastrophic disaster

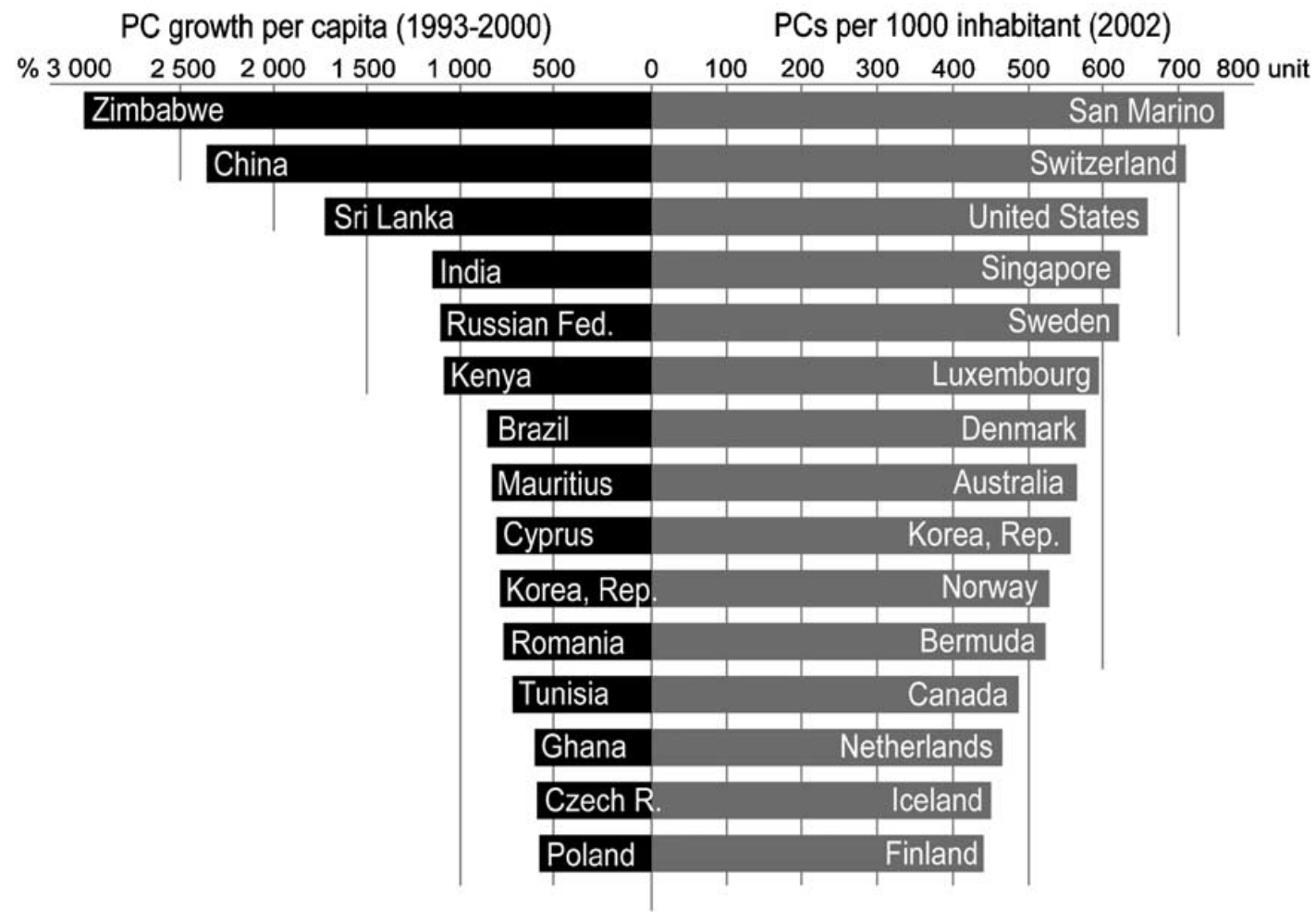

Fig. 3. Statistics for the personnel computer consumption in different countries to correlate E-waste generation (Widmera et al., 2005)

\section{E-wastes Challenges and Opportunities}

Today's E-gadget is tomorrow's waste. Therefore, E-waste production data can be articulated with the import or consumption of E-gadgets. The drastically increasing international trend of growing consumption is depicted in Fig 3. It shows a tremendously large volume of use of personal computers and smart devices in developed countries in comparison to developing and less developed countries.

In the parallel pattern, the study for television import in Nepal from 1999 to 2011 was found to increase by $58.12 \%$ (Mansfield 2013). The recent if disposed of in the land or water of Nepal (Pace Nepal Pvt. Ltd., 2017).

Nepal does not have a separate Act for E-wastes management to date. The E-wastes are collected along with other solid waste materials. In 2011 Nepal Government introduced regulation for a solution, E-waste Management (Solid Waste Management Act 2011), for all types of waste including industrial, domestic, medical, chemical, and E-wastes, which are unfortunately not being strictly implemented by concerned authorities (IPE Global Private Limited 2012). An earlier study showed that looking at a per-capita generation of solid waste, waste production is higher in the hilly 
region in comparison to tarai and mountains. Fig 4 (a) indicates that with urbanization, the creation of waste becomes higher as expected. The data clarifies that one person generates $283 \mathrm{~g}$ of solid waste per day. In the Nepalese society general concept of family members is 5 , so with this figure, one can easily articulate that a family produces $1 \mathrm{~kg}$ of solid waste in a day (Asian Development Bank 2013). A recent study further shows that only the Kathmandu valley produces 700 metric tons of solid wastes every day (Basnet 2014). Generally, the solid waste contains a majority of organic wastes $65 \%$, which can be easily composted; and the other inorganic wastes are less in composition. Fig 4(b) shows that the plastic waste fraction is $8 \%$, with metals contribution in total solid waste to $1.2 \%$, which primarily comes from E-waste real stakeholders of E-wastes in Nepal are the producers, household users, business houses, institutions, and electronic repair shops, which may have $50 \%$ or more E-waste stocks composed of the total stock of E-gadgets. The scavengers scrap hawkers, and scrap dealers collect all these E-wastes from the consumers. Similarly, the municipality is also one of the stakeholders for an authoritative action plan for waste disposal (Parajuly 2017).

In urban cities of Nepal, the waste disposal practice of household consumers is supported by the municipality. It collects all the wastes from different localities, in an entirely unplanned way and dumps for landfilling. For instance, Kathmandu Metropolitan City (KMC) authority

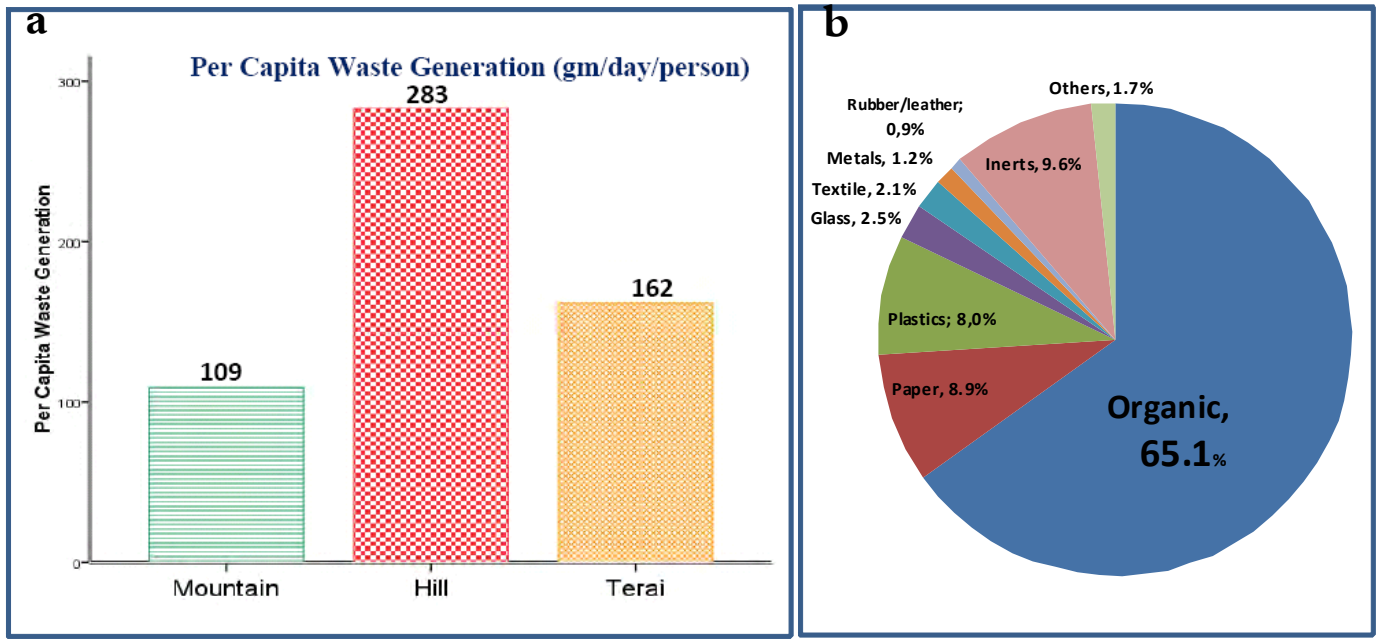

Fig. 4. (a) Plots for per capita waste generation in the Kathmandu valley. (b) Percentage distribution of different kinds of solid wastes disposed of in Kathmandu (Asian Development Bank 2013, PACE Nepal Pvt. Ltd. 2017)

(Asian Development Bank 2013, PACE Nepal Pvt. Ltd. 2017). The data on E-wastes makes it evident that in total, E-waste $21 \%$ is plastic, $50 \%$ is iron with steel, and $3 \%$ is other rare and expensive metals (Asian Development Bank 2013, PACE Nepal Pvt. Ltd. 2017). The proper management of E-waste followed with the recovery of these metals would introduce many opportunities to convert waste to resources.

\section{Nepal's Practice for E-waste Disposal}

Depending on the types of stakeholders who generate E- wastes, disposal practice varies. The collects all solid waste with the help of staff and vehicles from all the houses in a site selected in Kathmandu, Teku, shown in Fig 5. The solid wastes collected in Teku by KMC authority are subsequently transported to Okhharpauwa, Sisdol landfill site, without further separation or detoxification. Scavengers make a selection of some of the valued things from the collected wastes and sell to scrap dealers.

During the manufacturing of E-gadgets, some default samples are produced, which are also E-wastes. Likewise, business houses, offices, institutions also generate E-wastes in large 


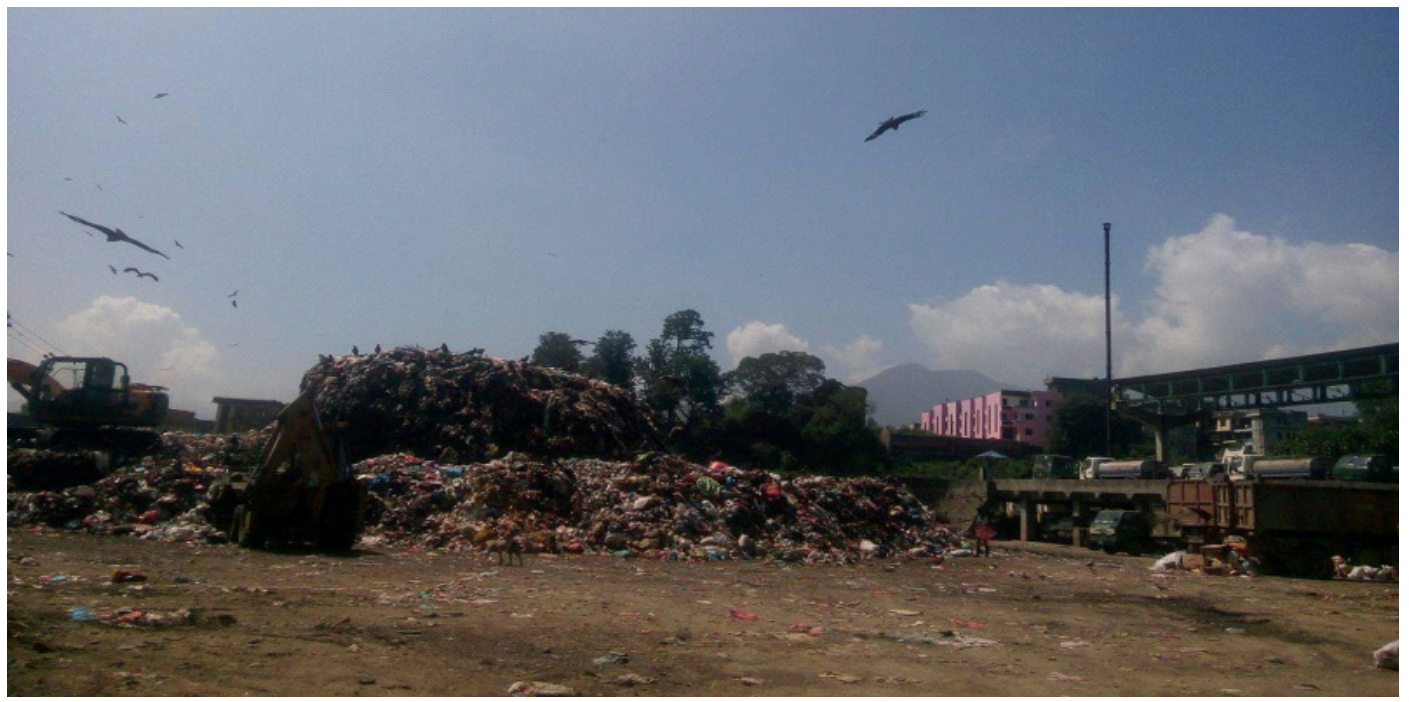

Fig. 5. Photograph showing solid waste collection site in Teku, Kathmandu

quantities after their full utilities with the advancement of technology in the universe. These producers dispose their E-waste by calling auctions. In similar ways, the repair shops have up to $50 \%$ of total E-waste collections, which are being sold to scrap dealers (Parajuly et al., 2017).

In Nepal, the general process of recycling is being done by scavengers, scrap hawkers, and scrap dealers, who separate the reusable parts and illegally export to a foreign country for proper recycling purposes, which seemingly need attention and monitoring by the concerned authority. The actual practices of waste disposal and recycling in Kathmandu are explained in Fig 6.

In rural areas, people simply dump all their waste products in nearby open places without proper knowledge, and sometimes the burning of nondegradable waste is being practiced in the open air, which is very unhealthy for living beings and the environment.

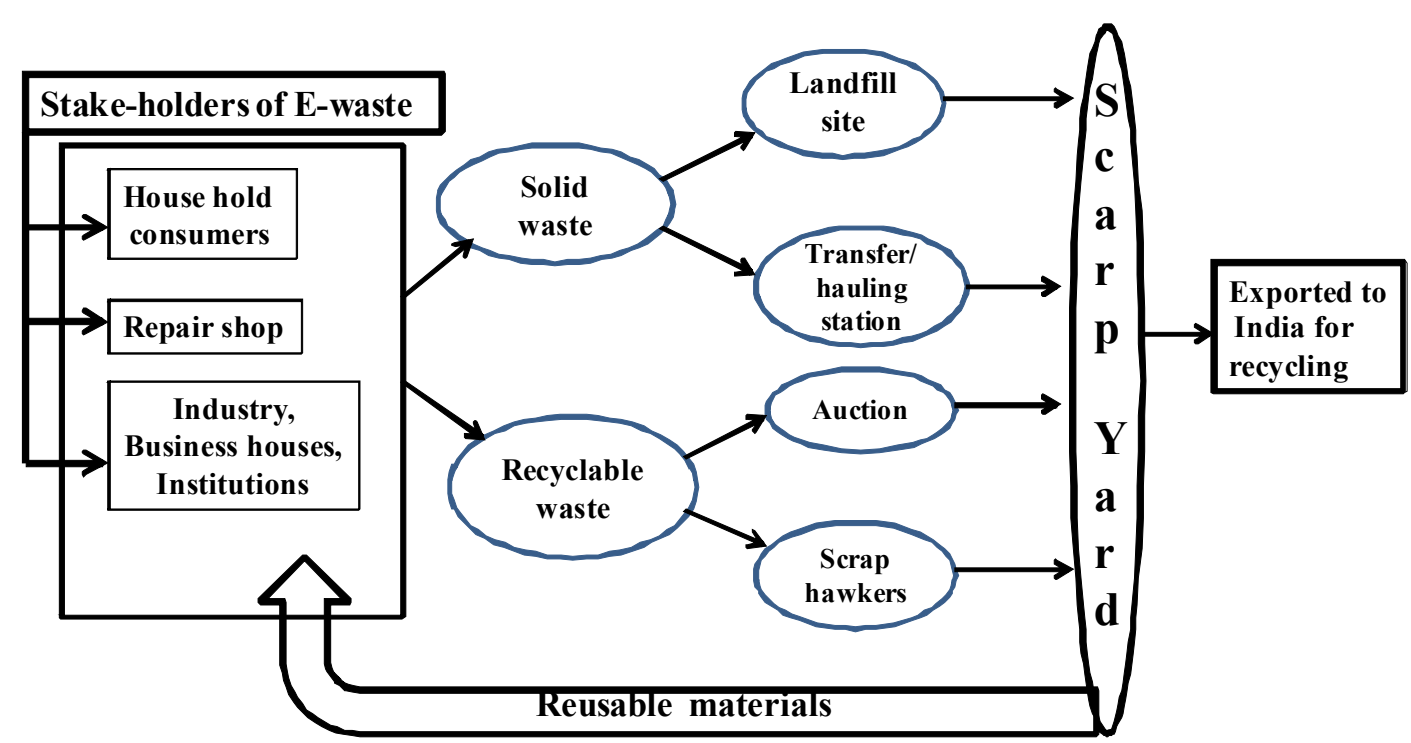

Fig. 6. Schematic chart showing different recycling patterns of solid wastes in Kathmandu valley 
Some of the young entrepreneurs have started an initiative to collect solid waste from the community for proper management.

\section{Suggestions and Solutions for Proper Management of E-wastes}

The increasing trend of consuming E-gadgets, including personal computers, which ultimately become mixed wastes, is one of the significant challenges. Meanwhile, the sophisticated lifestyle, decreasing market value of E-gadgets and easy access to the market, add more complexities in
(Sawhney et al., 2008; Asian Development Bank 2013).

As E-wastes are being discarded by the society unattended, the real practice for such things should be started from primary consumers by separating it from other wastes and help to dispose of in the correct place (Sawhney et al., 2008; Kalana 2010). Additionally, the manufacturer should take responsibility for the proper disposal of the product after being used (Mansfield 2013). The systematic process should start with the door to

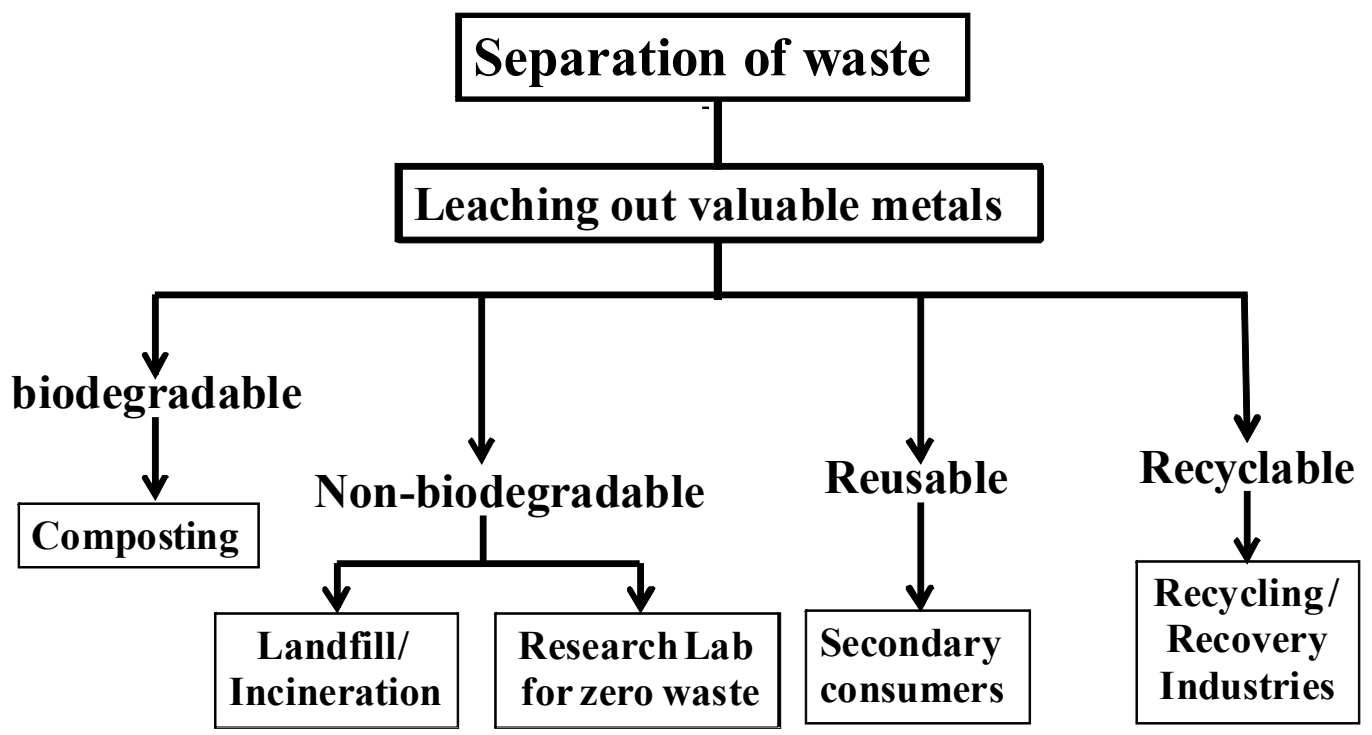

Fig. 7. Schematic outline showing different steps recommended for the proper E-waste management

the E-wastes management issues. (Widmera et al., .2005). The proper E-waste management is only possible if it lies in the national agenda of the country (Szalatkiewicz 2014), which is unfortunately not the case in our country. Nepal has not even been able to enforce the Solid Waste Management Act 2011 strictly. Thus, public awareness has become essential for targeting the reasonable outcome in solid wastes management, including E-wastes (IPE Global Pvt. Ltd. 2012; Asian Development Bank 2013).

Now, as E-wastes are always increasing, with an awakened mind, one should start to turn wastes into resources, which could support the circular economy of the country. The flow chart depicted in Fig 7 proposes the adoption of $3 \mathrm{R}$ principles with additional redesign policy for local purposes door collection of the E-wastes, leaching out the metal parts using safe chemical treatments such as acid leaching or some biological process (Musson 2000, PACE Nepal Pvt. Ltd., 2017).

The separated E-wastes should be categorized in four groups as shown in Fig 7; (i) biodegradable for composting, (ii) non-biodegradable for landfill or incineration that can be sent to the research laboratory and safe processing units for detoxification and further research to bring in other application so that the waste becomes completely zero, (iii) reusable for secondary consumers and (iv) recyclable to the industry which could be polymers and metal particles (Hiroki 1992, IPE Global Pvt. Ltd. 2012). The proposed format can be used to convert the most impertinent wastes into the resources for new applications and to save 
the environment for future generations (Brandl 2001).

\section{Conclusions}

The increasing E-waste in society pollutes natural environments, which could be quite dangerous for the wellbeing of life on the Earth. Therefore, the time has come to sense the urgency of proper management of E-waste. Thus, it is necessary to act now to ensure the safety of life and the natural environment on the planet. A few strategies are suggested below as guidelines for addressing the disastrous scenario of E-wastes and the urgency of proper management in Nepal.

1. An essential foundation towards this direction is to provide awareness to the manufacturer, consumers as well as to the general public about the responsible utilization of E-wastes and related management problems and possible hazards.

2. Nepal urgently needs regulatory guidelines to cope with the E-wastes problematic. Strict regulatory actions on both import and disposal should be implemented.

3. The knowledge on the production of E-wastes, hazards, and mitigation measures have to be incorporated in the curriculum of schools and universities.

4. The proposed path for the recovery of expensive and hazardous metals is an essential part of the management, which should be instantly followed by the concerned sectors. It may add an advantage to the economy of the country. Research works in this direction should be promoted.

5. Recycling and recovery of the polymer composites used in E-gadgets are also an essential part of the concern, while their safe incineration to produce energy may be useful. The non-degradable, toxic, and hazardous materials left behind can be studied for their useful applications or detoxification.

\section{Acknowledgments}

The authors would like to extend their sincere thanks to the former Minister for Environment, Science, and Technology Er. Ganesh Sah for his inspiration and motivation in this work. We further acknowledge the cordial support from Er. Guna Raj Dhakal, Mr. Purna N. Ranjitkar, and Mr. Sagar Kafle from Renewable Energy Confederation Nepal (RECoN) in carrying out research work in the field of E-Wastes. The authors are also grateful to the Nepal Academy of Science and Technology (NAST) for the Ph. D. Research Fellowship.

\section{References}

Ababio, M. O., 2012. Sustainable developmentauthoritative and leading-edge content for environmental management. Electronic waste management in Ghana-issues and practices: Chapter 7: 149-166 pp. ISBN 978-953-510682-1

Asian Development Bank. 2013. Solid Waste Management in Nepal Current Status and Policy Recommendations. 1-28 pp.

Basnet, D., 2014. Identification of landfill site by using geospatial technology and multicriteria method- a case study of Kathmandu, Bhaktapur, and Lalitpur district of Nepal. International Journal of Environment 4(1): 2091-2854.

Brandl, H., R. Bosshard, M. Wegmann. 2001. Computer-mulching microbes: metal leaching from electronic scrap by bacteria and fungi. Hydrometallurgy 59: 319-326.

Chen, C., K. Yang, C. Yu, Z. Qin, R. Huang, X. Tang, C. Shen, and H. Shi. 2015. Polychlorinated biphenyls attenuation in soil from the E-waste Recycling area under flooded and dryland conditions. Clean-Soil, Air, Water 43(4): 584-591.

Chen, M., O. A. Ogunseitan, H. Duan, X. Zeng, and J. Li. 2018. China E-waste management: Struggling for future success. Resources, Conservation \& Recycling 139: 48-49. https:// doi.org/10.1016/j.resconrec.2018.08.006

Dhungana, S., 2017. Nepal Telecommunication Authority. Consultation Paper on the regulatory framework for E-waste management April, https://thehimalayantimes.com/business/ nepal-telecommunications-authority-stress- 
es-regulatory-framework-e-waste-management/

International classification for waste (https:// www.iso.org/ics/13.030/x/).

Directive 2012/19/EU of the European Parliament and the council. 2012. On waste electrical and electronic equipment(WEEE). Official Journal of the European Union.

Dreher, K., and S. Pulver. 2008. Environment as 'high politics'? Explaining divergence in US and EU hazardous waste export policies. Review of European, Comparative \& International Environmental Law (RECIEL) 17(3): 306-318.

Dunne, L., F. J. Convery, and L. Gallagher. 2008. An investigation into waste charges in Ireland, with emphasis on public acceptability. Waste Management 28(12): 2826-2834.

DIRECTIVE 2012/19/EU. European Guideline for E-waste Management (2012). http:// ewasteguide.info/e_waste_definition (EU); accessed Sept. 15, 2017

Hiroki, M., 1992. Effects of heavy metal contamination on soil microbial population. Journal of Soil Science and Plant Nutrition 38(1): 141-147.

Hoornweq, D., and P. B. Tata. 2012. The World Bank. Urban development series - knowledge paper. What A Waste: A Global Review of Solid Waste Management 15: 4-7.

International Classification for Standards. 2015. Seventh edition, ISBN 978-92-6710652-6 (C) International Organization for Standardization, Retrived from: https://www. iso.org/files/live/sites/isoorg/files/archive/ pdf/en/international_classification_for standards.pdfIPE Global Private Limited. In association with Environment Resource Management Consultants (ERMC) (P.) Ltd. and Full Bright Consultancy (Pvt). Ltd. 2012. Solid Wastes Management Technical Support Centre (SWMTSC), Ministry of Federal Affairs and Local Development (MoFALD),
ADB TA-7597-NEP-Capacity Building for Waste Management, Final Report. September 2012. Submitted to Asian Development Bank, 1-17 pp.

Jarup, L., 2003. Hazards of heavy metal contamination. British Medical Bulletin 68: 167-182.

Joesph, K., 2007. Electronic waste management in India-issues and strategies. In: Proceedings of Eleventh International Waste Management and Landfill Symposium pp.1-9.

Kalana, J. A., 2010. Electrical and electronic waste management practice by households in Malaysia-Shah Alam, Selangor. International Journal of Environmental Sciences 1(2): 132144.

Karmacharya, A., P. Basnet, and V. K. Rana. 2015. Status of E-waste in Nepal and its mitigating measures through information communication technology. Conference on Information Technology 1-4.

Kaya, M., 2016. Recovery of metals and nonmetals from electronic waste by physical and chemical recycling processes. Waste Management 57: 64-90.

http://dx.doi.org/10.1016/j.wasman.2016.08.004

Mansfield, K. 2013. Electronic waste disposal in the European Union: Avoiding the once-ler's dilemma. Environmental Studies Program at the University of Vermont. 17-51.

Mihai, F.-C., 2019. Electronic waste management in Romania: pathways for sustainable practices. In: Narasimha, M., V. Prasad, M. Vithanage, A. Borthakur(Editors). Chapter 22, Handbook of Electronic Waste Management: International Best Practices and Case Studies, 1st Edition, ISBN: 9780128170304, Butterworth-Heinemann. DOI: https://doi. org/10.1016/B978-0-12-817030-4.00024-3

Musson, S. E., C. J. Yong, T. G. Townsend, and I. H. Chung. 2000. Characterization of lead leachability from cathode ray tubes using the toxicity characteristic leaching procedure. 
Environmental Science Technology Letters 34(20): 4376-4381.

Narasimha, M., V. Prasad, M. Vithanage, and A. Borthakur (Editors). 2019. Handbook of Electronic Waste Management: International Best Practices and Case Studies 1st Edition, ISBN: 9780128170304, Elsevier Inc.

Nnorom, I. C. and O. A. Odeyingbo, 2020, Electronic waste management practices in Nigeria, Chapter 14, In Handbook of Electronic Waste Management: International Best Practices and Case Studies, 1st Edition, ISBN: 9780128170304, Elsevier Inc.

Oppelt, E.T., 1987. Incineration of hazardous waste. Journal of the Air and Waste Management Association 37(5): 558-586.

PACE Nepal Pvt. Ltd. 2017. Final Report on Inventory Preparation of E-Waste and Its Management in Kathmandu Valley Submitted to the Department of Environment.

Parajuly, K., K. Thapa, C. Cimpan, and Henrik Wenzel. 2017. Electronic waste and informal recycling in Kathmandu, Nepal: Challenges and opportunities. Journal of Material Cycles and Waste Management. Regional case study $1-11$.

Peterson, M., 2009. Heavy metal toxicity, Minerals that can poison the body and cause chronic illness. Suite101.com. 1-6.

Premalatha, M., T. Abbasi, T. Abbasi, and S. A. Abbas. 2014. The Generation, Impact, and Management of E-Waste: State of the Art. Critical Reviews in Environmental Science and Technology 44: 1577-1678.

Sawhney, P., M. Henzler, S. Melnitzky, and A. Lung. 2008. Best practices for e-waste management in Developed countries. August. Adelphi Research, EuropeAid Cooperation pp. 6-9.

Szalatkiewicz, J., 2014. Metals content in printed circuit board waste. Police Journal of Environmental Studies 23(6): 2365-2369.
Shaikh, S., K. Thomas, and S. Zuhair. 2020. An exploratory study of e-waste creation and disposal: Upstream Considerations. Resources, Conservation \& Recycling 155: 104662

doi.org/10.1016/j.resconrec.2019.104662. Terazono, A., S. Murakami, N. Abe, B. Inanc, Y. Moriguchi, S. I. Sakai, M. Kojima, A. Yoshida, J. Li, J. Yang, M. H. Wong, A. Jain, I. S. Kim, G. L. Peralta, C. C. Lin, T. Mungcharoen and E. Williams. 2006. Current status and research on E-waste issues in Asia. Journal of Materials Cycles and Waste Management 8: 1-12.

The European Communities. 2003. Section 4-Waste management legislation. Handbook on the Implementation of EC Environmental Legislation, 395-608.

Tyagi, M., and D. Tyagi. 2014. Polymer nanocomposites and their applications in the electronics industry. International Journal of Electronics and Electrical Engineering 7: 603-608.

Widmera, R., H. O. Ktapf, D. S. Khetriwal, M. Schnellmann, and H. Bonia. 2005. Global perspectives on E-Waste. Environmental Impact Assessment Review 25: 436-458.

Wu, J. P., X. J. Luo, Y. Zhang, Y. Luo, S. J. Chen, B.X. Mai, and Z. Y. Yang. 2008. Bioaccumulation of polybrominated diphenyl ethers (PBDEs) and Polychlorinated biphenyls (PCBs) in wild aquatic species from electronic waste (E-waste) recycling site in South China. Environment International 34(8): 1109-1113.

Xu, S, H. He, L. Luo, H. He, and L. Luo. 2016. Status and Prospects of Municipal solid waste to Energy Technologies in China. Recycling of Solid Waste for Biofuels and Bio-Chemicals, Environmental Footprints, and Eco-design of Products and Processes 31-54.

Zaman, A. U., and S. Lehmann. 2013. The zerowaste index: a performance measurement 
Nepal Journal of Science and Technology (NJST) (2020), 19(1)

tool for waste management systems in 'zero waste city.' Journal of Cleaner Production 50: 123-132.

Zeng, X., H. Duan, F. Wang, and J. Li. 2017 a. Examining environmental management of e-waste: China's experience and lessons. Renewable and Sustainable Energy Reviews 72:1076-1082.https://doi.org/10.1016/ j.rser.2016.10.015

Zeng, X., C. Yang, J. F. Chiang, and J. Li. 2017 b. Innovating e-waste management: From macroscopic to microscopic scales. Science of the Total Environment 575: 1-5 